\author{
Ş. Güvenç, V. John \& A. Türk
}

\title{
Phytogeographical analysis of the lichens and lichenicolous fungi of Turkey
}

\begin{abstract}
Güvenç, S., John, V. \& Türk, A.: Phytogeographical analysis of the lichens and lichenicolous fungi of Turkey. - Borziana 1: 87-108. 2020.

The aim of the paper is to evaluate the diversity of all known lichenized and lichenicolous fungi of the Turkish provinces, their similarities being calculated and to determine their distribution in the geographic and phytogeographic regions of Turkey. The records of lichenized fungi in "A Checklist of the Lichens of Turkey" were evaluated, together with new country and province records from 2015 to 2020 . A total of 1765 lichenized fungi were evaluated from the 81 provinces. The geographical regions of Turkey were divided into three main groups according to the similarity in species diversity (1) Aegean, Mediterranean and Marmara, (2) Central, Eastern and Southeastern Anatolia, and (3) the Black Sea region. The phytogeographical regions of Turkey were divided into two main groups (1) Euro-Siberian and Mediterranean and (2) Irano-Turanian. The very heterogeneous intensity so far of the research on lichens in the different provinces of Turkey causes only a weak correlation of the distribution of lichens with the geographic and phytogeographic regions.
\end{abstract}

Key words: biodiversity, checklist, distribution, lichen biota, phytogeography.

\section{Introduction}

Turkey is rich in biodiversity, endemics and floristic hotspots of three phytogeographic regions. While the flora of higher plants is well documentated (Eken \& al. 2006; Güner \& Ekim 2012; Güner 2014; Dönmez \& Yerli 2019), literature on lichens in Turkey so far is scattered in 762 papers. Lichenology in Turkey began with field trips by foreign lichenologists in the second half of the 20th century, and studies on its lichen flora by Turkish scientists started in the 1980s (John 2007a). A first regional checklist of lichens was limited to the Mediterranean region (John 1996) and listed 459 infrageneric taxa from 128 genera, and 2012 the number of lichenicolous fungi of Turkey gradually increased to 177 (Halic1 \& al. 2012). Up to 2015, 682 studies had been published (John \& Türk 2017), and 1887 taxa (1849 species and 38 subspecies or varieties) consisting of 1679 lichens and 208 lichenicolous fungi were listed in the checklist of lichens of Turkey. This first comprehensive summary in Turkish language unfortunately does not contain any statistics on the number of species in the provinces. 
This will be made up for here. In the five-year period (2015-2020), 707 additional lichens and lichenicolous fungi have been recorded for 30 provinces (John \& al. 2020). Merging the data from these two compilations, here an overview over the number of species in the 81 provinces is presented. It should be further tested whether the provinces (administrative units) are usefull as mapping units to characterise geographical or phytogeographical regions.

\section{Materials and Methods}

\section{Biodiversity, Climate and Topography of the study area}

Turkey is divided into 81 provinces and seven geographical regions, namely, Aegean, Marmara, Black Sea, Eastern Anatolia, Southeastern Anatolia, Mediterranean, and Central Anatolia (FAO 2018). Each of the regions have unique climatic and ecological features which can change sharply over very short distances.

Anatolia consists of an inner high plateau bordered by west-to-east mountain ranges along the north and south coasts. The southern mountain range (Taurus) at the west is close to the Mediterranean coast and continues north-eastward as the Anti-Taurus. Central Anatolia is a high plateau at an elevation between 800 and 1,000 m. In the north of Anatolia, mountain ranges are higher and closer to the sea towards the east, allowing a narrow, green and fertile belt along the Black Sea coast. An elevation of some mountain ranges in the Black Sea Region is rise to over 3,000 m. Eastern Anatolia region is rugged land with high elevations, a more severe climate, and greater precipitation than on the Central Anatolia. The average elevation of the peaks is greater than 2,000 m. Ağrı mountain (5,172 m) which is the highest point of Turkey is in this area. Eastern Anatolia is the largest region of Turkey with 21\% of the total area of the country. Southeastern Anatolia is much lower and flatter than Eastern Anatolia, an elevation is falling from $800 \mathrm{~m}$ in the north to $400 \mathrm{~m}$ at the Syrian border.

The climate of Turkey is divided with several major climate types. The subtropical steppe climate is found in the middle part of the Central Anatolia Region, and the Van-Iğdır district over the most-eastern part of the Eastern Anatolia Region. The temperate (rainy or humid) climate without a dry season is predominantly found in the Black Sea Region with the exception of the western sub-region. The Mediterranean climate with a dry summer season is found in Marmara, Aegean, Mediterranean and Southeastern Anatolia Regions, and the western and southern parts of the Central Anatolia Region. The cold snowy forest climate with a dry summer is found over a relatively large zone including the middle-northern parts of the Central and Eastern Anatolia Regions of Turkey. The cold snowy forest climate with humid in all seasons is found over relatively small areas in the northern parts of the Central Anatolia Region. In addition, it is found at the vicinities of Erzurum-Kars provinces in the northern parts of Eastern Anatolia region of Turkey. The mean annual temperatures varies widely throughout the country influenced by elevation, topography, and orientation about maritime or continental conditions. Throughout the year, highest temperatures are recorded in July and August. Average temperature during these two months is $27^{\circ} \mathrm{C}$ on Mediterranean and Aegean coasts and $22-24{ }^{\circ} \mathrm{C}$ on the Marmara and Black Sea coasts. The mean annual temperature is $18-20{ }^{\circ} \mathrm{C}$ on the south coast (Mediterranean region) of Turkey, and is falls to $14-15^{\circ} \mathrm{C}$ on the west coast (Aegean). The mean annual temperature is varies between 4 to $18{ }^{\circ} \mathrm{C}$ depending on the elevation in the interior parts of Turkey (FAO 2018). 
Turkey is situated at the junction of three of the world's phytogeographical regions: EuroSiberian, Mediterranean, and Irano-Turanian. Mediterranean elements are dominant in the Mediterranean and Aegean regions and the southern parts of the Marmara region. The EuroSiberian element is comprised of the mountainous forest in Black Sea and the northern of Marmara regions of Turkey. The Irano-Turanian element includes the steppes of Central, Eastern and Southeastern Anatolia. Turkey's temperate forests consist of coniferous $(60.8 \%$ of total forested area) and broad-leaved deciduous (39.2\%) forests and cover $27.3 \%$ of the country. Coniferous forests around the Mediterranean (Pinus brutia, Pinus nigra, Abies cilicica, Cedrus libani) range from sea level to $2,000 \mathrm{~m}$, while Black Sea region conifers (Pinus sylvestris, Fagus orientalis, Abies nordmanniana) are found primarily between 1000 and $1200 \mathrm{~m}$. Broad-leaved deciduous forests consist of Castanea, Carpinus, Tilia, Alnus, and Acer species, and prevail at lower elevations. Steppes covering $27 \%$ of Turkey are particularly dominant in an arc from central to southeastern Anatolia with 20-60 mm annual rainfall (Şekercioğlu \& al. 2011). Due to Turkey's position as a bridge between Europa and Asia continents has a different climatic and geographical features. Therefore, it has a rich biodiversity with forest, mountain, and steppe, wetland, coastal and marine ecosystems and different forms and combinations thereof. Turkey is one of the world's richest countries with regard to diversity of plant species. The number of known native vascular plant species is more than 11,000 and endemic taxa is 3,649 (Güner \& al. 2016).

The lichens published in John \& Türk (2017) and John \& al. (2020) provide the basis for the evaluation, in all 16,173 lichen records. The records of the lichens have been studied for their correlation with specific provinces of the geographical and phytogeographical regions. The assessed provinces in the geographical regions of Turkey are given in Table 1 and attribution of provinces to geographical regions are mapped in Fig. 1. Similarly, the assessed provinces in the phytogeographical regions are given in Table 2 and the attribution of provinces to phytogeographical regions are mapped in Fig. 2.

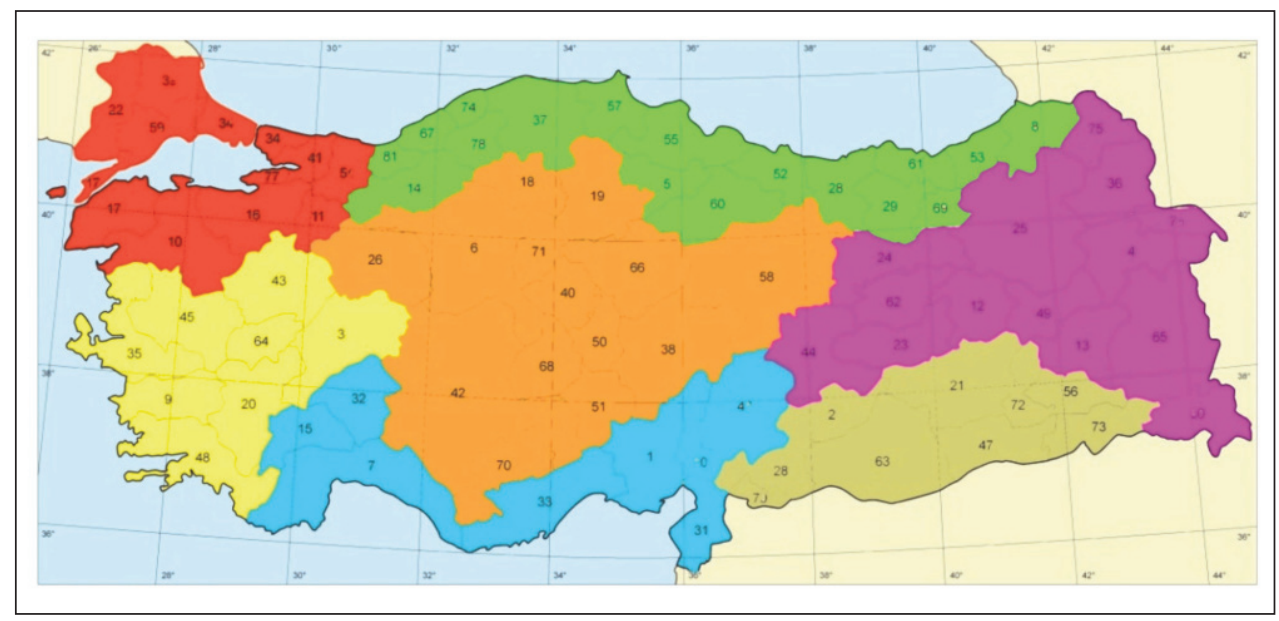

Fig. 1. Attribution of provinces to geographical regions. Map: V. John, original. 
Table 1. The geographical regions of the provinces in Turkey (FAO 2018).

\begin{tabular}{|c|c|}
\hline $\begin{array}{l}\text { Geographic } \\
\text { Regions }\end{array}$ & Code-Numbers and names of the Provinces \\
\hline Aegean Region & $\begin{array}{l}\text { 03: Afyonkarahisar, 09: Aydın, 20: Denizli, 35: İzmir, 43: } \\
\text { Kütahya, 45: Manisa, 48: Muğla, 64: Uşak }\end{array}$ \\
\hline Black Sea Region & $\begin{array}{l}\text { 05: Amasya, 08: Artvin, 74: Bartın, 69: Bayburt, 14: Bolu, 19: } \\
\text { Çorum, 81: Düzce, 28: Giresun, 29: Gümüşhane, 78: Karabük, 37: } \\
\text { Kastamonu, 52: Ordu, 53: Rize, 55: Samsun, 57: Sinop, 60: Tokat, } \\
\text { 61: Trabzon, 67: Zonguldak }\end{array}$ \\
\hline Central Anatolia & $\begin{array}{l}\text { 68: Aksaray, 06: Ankara, 18: Çankırı, 26: Eskişehir, 70: Karaman, } \\
\text { 38: Kayseri, 71: Kırıkkale, 40: Kırşehir, 42: Konya, 50: Nevşehir, } \\
\text { 51: Niğde, 58: Sivas, 66: Yozgat }\end{array}$ \\
\hline natolia & $\begin{array}{l}\text { 04: Ağrı, 75: Ardahan, 12: Bingöl, 13: Bitlis, 23: Elazı̆̆, 24: } \\
\text { Erzincan, 25: Erzurum, 30: Hakkâri, 76: Iğdır, 36: Kars, 44: } \\
\text { Malatya, 49: Muş, 62: Tunceli, 65: Van }\end{array}$ \\
\hline Marmara Region & $\begin{array}{l}\text { 10: Balıkesir, 11: Bilecik, 16: Bursa, 17: Çanakkale, 22: Edirne, } \\
\text { 34: İstanbul, 39: Kırklareli, 41: Kocaeli, 54: Sakarya, 59: } \\
\text { Tekirdağ, 77: Yalova }\end{array}$ \\
\hline Mediterranean & $\begin{array}{l}\text { 01: Adana, 07: Antalya, 15: Burdur, 31: Hatay, 32: Isparta, 46: } \\
\text { Kahramanmaraş, 33: Mersin, 80: Osmaniye }\end{array}$ \\
\hline $\begin{array}{l}\text { Southeastern } \\
\text { Anatolia }\end{array}$ & $\begin{array}{l}\text { 02: Adıyaman, 72: Batman, 21: Diyarbakır, 27: Gaziantep, 79: } \\
\text { Kilis, 47: Mardin, 56: Siirt, 63: Şanlıurfa, 73: Şırnak }\end{array}$ \\
\hline
\end{tabular}

Table 2. The assessed provinces in the phytogeographical regions of Turkey (FAO 2018).

\begin{tabular}{|l|l|}
\hline $\begin{array}{l}\text { Phytogeographic } \\
\text { Regions }\end{array}$ & Provinces \\
\hline $\begin{array}{l}\text { Euro-Siberian } \\
\text { (Colchic) }\end{array}$ & Artvin, Giresun, Rize, Trabzon \\
\hline $\begin{array}{l}\text { Euro-Siberian } \\
\text { (Euxine) }\end{array}$ & $\begin{array}{l}\text { Amasya, Bartın, Bolu, Bursa, Düzce, Edirne, Karabük, } \\
\text { Kastamonu, Kırklareli, Kocaeli, Ordu, Sakarya, Samsun, Sinop, } \\
\text { Tekirdağ, Tokat, Yalova, Zonguldak }\end{array}$ \\
\hline & $\begin{array}{l}\text { Adıyaman, Afyonkarahisar, Ağrı, Aksaray, Ankara, Ardahan, } \\
\text { Batman, Bayburt, Bilecik, Bingöl, Bitlis, Çankırı, Çorum, } \\
\text { Diyarbakır, Elazığ, Erzincan, Erzurum, Eskişehir, Gaziantep, } \\
\text { Gümüşhane, Hakkâri, Iğdır, Karaman, Kars, Kayseri, Kırıkkale, } \\
\text { Krano-Turanian } \\
\text { Nevşehir, Kilis, Konya, Kütahya, Malatya, Mardin, Muş, Sivas, Şanlıurfa, Şırnak, Tunceli, Uşak, } \\
\text { Van, Yozgat }\end{array}$ \\
\hline \multirow{2}{\text{Mediterranean}}{} & $\begin{array}{l}\text { Adana, Antalya, Aydın, Balıkesir, Burdur, Çanakkale, Denizli, } \\
\text { Hatay, Isparta, İstanbul, İzmir, Manisa, Mersin, Muğla, } \\
\text { Kahramanmaraş, Osmaniye. }\end{array}$ \\
\hline
\end{tabular}




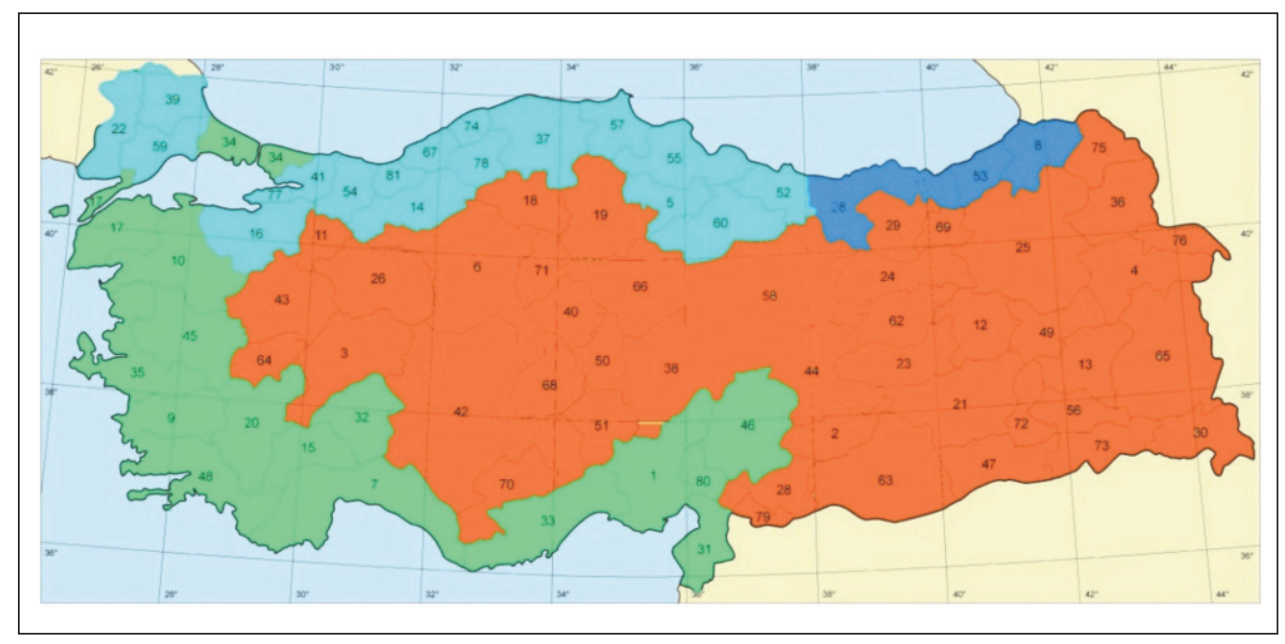

Fig. 2. Attribution of the provinces to phytogeographical regions.

\section{Statistical Analyses}

Standard statistical analyses were conducted (Statistics 23, SPSS, IBM, Armonk, New York, United States). Ward's Hierarchical Clustering Method with Squared Euclidean Distance was used to obtain dendrograms of similarities based on the nearest-neighbor chain algorithm and lichen diversity. To determine mean differences of geographic and phytogeographic regions of Turkey, Two-Way ANOVA with Tukey's HSD (honestly significant difference) test, as single-step multiple comparison procedure and statistical test was used. Correlations between Shannon-Wiener-Index $\left(H_{s}\right.$, the symbol for the extent of heterogeneity in a group of $s$ species) for diversity values in the geographical and phytogeographical regions, as well as the axes, were assessed using the Pearson correlation coefficient (2tailed). Here, Shannon-Wiener index (species diversity value, MSDV) was used as the diversity in the provinces. The data matrix based on the presence and absence of the species in the provinces ( 1765 species $\times 81$ province) was used for the statistical evaluation in the CANOCO program ver. 4.5. Ordination diagrams of the geographical and phytogeographical regions were obtained by using the indirect linear model with Principal Component Analysis (PCA) in CANOCO (Ter Braak \& Smilauer 2002). Indicator species analysis was conducted with TWINSPAN for Windows Version 2.3 (Hill \& Smilauer 2005).

\section{Results}

The provinces with the highest number of lichen taxa are Trabzon (607) and Bursa (606), followed by Giresun (597), Kayseri (482), Eskişehir (464), Antalya (431) and Isparta (410) (Table 3). Clearly, the presence of local researchers specializing in lichens in these provinces, except for Isparta, is closely related to these results. 
Table 3. Number of lichenicolous and lichenized fungi in the provinces of Turkey.

\begin{tabular}{|c|c|c|c|c|c|c|c|c|}
\hline \multirow[b]{2}{*}{ Province } & \multirow[b]{2}{*}{ 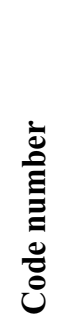 } & \multicolumn{3}{|c|}{\begin{tabular}{|c|} 
Records in \\
John \& Türk (2017) \\
\end{tabular}} & \multicolumn{3}{|c|}{$\begin{array}{c}\text { Records in } \\
\text { John \& al. (2020) }\end{array}$} & \multirow{2}{*}{ 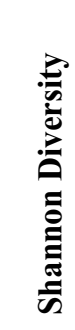 } \\
\hline & & 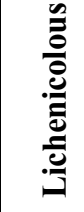 & 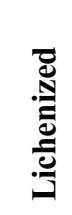 & हٓ & 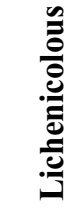 & 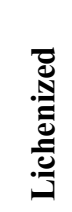 & है & \\
\hline Adana & 01 & 13 & 186 & 199 & 0 & 0 & 199 & 5.23 \\
\hline Adryaman & 02 & 5 & 197 & 202 & 0 & 5 & 207 & 5.31 \\
\hline Afyonkarahisar & 03 & 7 & 152 & 159 & 48 & 189 & 397 & 5.83 \\
\hline Ăgrn & 04 & 6 & 49 & 55 & 0 & 1 & 56 & 3.91 \\
\hline Aksaray & 68 & 1 & 134 & 135 & 0 & 0 & 135 & 4.91 \\
\hline Amasya & 05 & 0 & 48 & 48 & 0 & 0 & 48 & 3.87 \\
\hline Ankara & 06 & 10 & 206 & 216 & 0 & 0 & 216 & 5.33 \\
\hline Antalya & 07 & 4 & 386 & 390 & 0 & 38 & 432 & 6.06 \\
\hline Ardahan & 75 & 6 & 362 & 368 & 0 & 1 & 369 & 5.89 \\
\hline Artvin & 08 & 7 & 198 & 205 & 0 & 2 & 207 & 5.30 \\
\hline Aydın & 09 & 2 & 201 & 203 & 1 & 2 & 206 & 5.31 \\
\hline Balıkesir & 10 & 5 & 255 & 260 & 1 & 101 & 362 & 5.88 \\
\hline Bartın & 74 & 0 & 72 & 72 & 0 & 0 & 72 & 4.28 \\
\hline Batman & 72 & 0 & 33 & 33 & 0 & 0 & 33 & 3.50 \\
\hline Bayburt & 69 & 2 & 156 & 158 & 1 & 0 & 159 & 5.05 \\
\hline Bilecik & 11 & 1 & 185 & 186 & 0 & 0 & 186 & 5.22 \\
\hline Bingöl & 12 & 0 & 19 & 19 & 1 & 6 & 26 & 3.22 \\
\hline Bitlis & 13 & 3 & 89 & 92 & 3 & 2 & 97 & 4.50 \\
\hline Bolu & 14 & 12 & 301 & 313 & 0 & 8 & 321 & 5.73 \\
\hline Burdur & 15 & 5 & 365 & 370 & 3 & 13 & 386 & 5.94 \\
\hline Bursa & 16 & 12 & 451 & 463 & 1 & 143 & 607 & 6.39 \\
\hline Çanakkale & 17 & 6 & 303 & 309 & 0 & 1 & 310 & 5.72 \\
\hline Çankırı & 18 & 1 & 94 & 95 & 0 & 11 & 106 & 4.65 \\
\hline Çorum & 19 & 0 & 176 & 176 & 1 & 2 & 179 & 5.18 \\
\hline Denizli & 20 & 6 & 232 & 238 & 20 & 83 & 341 & 5.75 \\
\hline Diyarbakır & 21 & 0 & 32 & 32 & 0 & 0 & 32 & 3.47 \\
\hline Düzce & 81 & 0 & 29 & 29 & 0 & 0 & 29 & 3.37 \\
\hline Edirne & 22 & 1 & 89 & 90 & 0 & 0 & 90 & 4.49 \\
\hline Elazı̆ & 23 & 10 & 185 & 195 & 2 & 7 & 204 & 5.26 \\
\hline Erzincan & 24 & 1 & 208 & 209 & 0 & 0 & 209 & 5.34 \\
\hline Erzurum & 25 & 2 & 240 & 242 & 0 & 5 & 247 & 5.50 \\
\hline Eskişehir & 26 & 18 & 282 & 300 & 18 & 147 & 465 & 6.06 \\
\hline Gaziantep & 27 & 4 & 124 & 128 & 0 & 0 & 128 & 4.82 \\
\hline Giresun & 28 & 8 & 419 & 427 & 3 & 167 & 597 & 6.37 \\
\hline Gümüşhane & 29 & 6 & 249 & 255 & 0 & 2 & 257 & 5.53 \\
\hline Hakkâri & 30 & 0 & 33 & 33 & 0 & 0 & 33 & 3.50 \\
\hline Hatay & 31 & 6 & 318 & 324 & 0 & 0 & 324 & 5.76 \\
\hline Iğdır & 76 & 37 & 302 & 339 & 0 & 0 & 339 & 5.71 \\
\hline
\end{tabular}


Table 3. continued.

\begin{tabular}{|c|c|c|c|c|c|c|c|c|}
\hline Isparta & 32 & 2 & 187 & 189 & 20 & 202 & 411 & 5.96 \\
\hline İstanbul & 34 & 8 & 302 & 310 & 1 & 43 & 354 & 5.84 \\
\hline İzmir & 35 & 26 & 283 & 309 & 0 & 2 & 311 & 5.65 \\
\hline Kahramanmaraş & 46 & 1 & 62 & 63 & 0 & 2 & 65 & 4.16 \\
\hline Karabük & 78 & 1 & 163 & 164 & 1 & 94 & 259 & 5.55 \\
\hline Karaman & 70 & 3 & 8 & 11 & 0 & 0 & 11 & 2.08 \\
\hline Kars & 36 & 2 & 63 & 65 & 0 & 0 & 65 & 4.14 \\
\hline Kastamonu & 37 & 10 & 247 & 257 & 0 & 1 & 258 & 5.52 \\
\hline Kayseri & 38 & 59 & 424 & 483 & 0 & 0 & 483 & 6.05 \\
\hline Kirıkkale & 71 & 0 & 21 & 21 & 0 & 0 & 21 & 3.05 \\
\hline Kirklareli & 39 & 1 & 183 & 184 & 0 & 0 & 184 & 5.21 \\
\hline Kırşehir & 40 & 2 & 97 & 99 & 0 & 0 & 99 & 4.58 \\
\hline Kilis & 79 & 0 & 8 & 8 & 0 & 0 & 8 & 2.08 \\
\hline Kocaeli & 41 & 1 & 132 & 133 & 0 & 0 & 133 & 4.88 \\
\hline Konya & 42 & 33 & 326 & 359 & 1 & 0 & 360 & 5.79 \\
\hline Kütahya & 43 & 3 & 170 & 173 & 0 & 8 & 181 & 5.19 \\
\hline Malatya & 44 & 21 & 219 & 240 & 0 & 4 & 244 & 5.40 \\
\hline Manisa & 45 & 21 & 124 & 145 & 4 & 179 & 328 & 5.71 \\
\hline Mardin & 47 & 1 & 60 & 61 & 0 & 0 & 61 & 4.09 \\
\hline Mersin & 33 & 1 & 112 & 113 & 1 & 2 & 116 & 4.74 \\
\hline Muğla & 48 & 7 & 219 & 226 & 0 & 4 & 230 & 5.41 \\
\hline Muș & 49 & 0 & 0 & 0 & 0 & 10 & 10 & 1.95 \\
\hline Nevşehir & 50 & 3 & 105 & 108 & 0 & 4 & 112 & 4.69 \\
\hline Niğde & 51 & 30 & 264 & 294 & 0 & 1 & 295 & 5.58 \\
\hline Ordu & 52 & 6 & 380 & 386 & 0 & 0 & 386 & 5.94 \\
\hline Osmaniye & 80 & 0 & 145 & 145 & 0 & 0 & 145 & 4.98 \\
\hline Rize & 53 & 7 & 303 & 310 & 0 & 3 & 313 & 5.72 \\
\hline Sakarya & 54 & 1 & 200 & 201 & 0 & 0 & 201 & 5.30 \\
\hline Samsun & 55 & 1 & 121 & 122 & 0 & 0 & 122 & 4.80 \\
\hline Siirt & 56 & 1 & 38 & 39 & 0 & 0 & 39 & 3.64 \\
\hline Sinop & 57 & 3 & 198 & 201 & 0 & 0 & 201 & 5.29 \\
\hline Sivas & 58 & 13 & 165 & 178 & 2 & 9 & 189 & 5.16 \\
\hline Şanlıurfa & 63 & 0 & 114 & 114 & 0 & 0 & 114 & 4.74 \\
\hline Şırnak & 73 & 0 & 10 & 10 & 0 & 1 & 11 & 2.40 \\
\hline Tekirdağ & 59 & 0 & 87 & 87 & 0 & 0 & 87 & 4.47 \\
\hline Tokat & 60 & 0 & 96 & 96 & 1 & 9 & 106 & 4.65 \\
\hline Trabzon & 61 & 19 & 583 & 602 & 0 & 3 & 605 & 6.37 \\
\hline Tunceli & 62 & 0 & 0 & $\mathbf{0}$ & 2 & 123 & 125 & 4.81 \\
\hline Uşak & 64 & 8 & 255 & 263 & 0 & 3 & 266 & 5.55 \\
\hline Van & 65 & 2 & 109 & 111 & 0 & 0 & 111 & 4.69 \\
\hline Yalova & 77 & 0 & 70 & 70 & 0 & 0 & 70 & 4.25 \\
\hline Yozgat & 66 & 16 & 160 & 176 & 1 & 4 & 181 & 5.10 \\
\hline Zonguldak & 67 & 7 & 256 & 263 & 0 & 0 & 263 & 5.55 \\
\hline Total lichen taxa & & 208 & 1679 & 1887 & 23 & 86 & \multicolumn{2}{|c|}{1996} \\
\hline \multicolumn{7}{|c|}{\begin{tabular}{|c|} 
Total lichenicolous taxa \\
\end{tabular}} & \multicolumn{2}{|c|}{231} \\
\hline \multicolumn{7}{|c|}{ Total lichenized taxa } & \multicolumn{2}{|c|}{1765} \\
\hline
\end{tabular}


Climatic variables (atmospheric humidity, temperature and precipitation) are among the most important factors controlling the distribution of lichens in a region (Hauck 2011). There is a close relationship between lichen diversity and climatic characteristics of the provinces. Aydın, İzmir and Muğla provinces which are close to each other and have similar climatic characteristics (Atalay \& al. 2014) are located side by side in Fig. 3. The situation is the same for Balıkesir, Çanakkale and Istanbul provinces on the coastal part of the Marmara Sea. Bursa, Giresun and Trabzon with the highest lichen diversity value and similar climatic characteristics are in the same group. Antalya with high lichen diversity is in a different group due to the effects of coastal Mediterranean climate.

The most common species of Turkey is Protoparmeliopsis muralis (Schreb.) M.Choisy in 74 of 81 provinces. It is followed by Candelariella aurella (Hoffm.) Zahlbr., C. vitellina (Hoffm.) Müll. Arg., Athallia holocarpa (Hoffm.) Arup, Frödén \& Søchting, Circinaria calcarea (L.) A. Nordin, Savić \& Tibell, Rhizocarpon geminatum Körb. and Myriolecis crenulata (Ach.) Śliwa, Zhao Xin \& Lumbsch, respectively (Table 4).

Alectoria sarmentosa (Ach.) Ach., with a cool-temperate to boreal-montane distribution, is very sensitive to air pollution and forest management (Nimis 2016). It was found only in the Black Sea and the Marmara geographic regions of Turkey. Aspicilia desertorum (Kremp.) Mereschk., a xeric subtropical lichen growing on hard, more or less calciferous rocks and dolomite (Nimis 2016), is mostly found in Eastern and Central Anatolia geographic regions, while Circinaria esculenta (Pall.) Sohrabi is in Eastern and Southeastern Anatolia.

Physcia adscendens H.Olivier, Physcia aipolia (Ehrh. ex Humb.) Fürnr. and Xanthoria parietina (L.) Th.Fr. are more common in the Aegean, Mediterranean and Marmara regions than in other regions. Physconia grisea (Lam.) Poelt and Physconia distorta (With.) J.R.Laundon are most frequent in Marmara region. Candelariella xanthostigma (Pers. ex Ach.) Lettau and Phaeophyscia nigricans (Flörke) Moberg are common species in Aegean and Marmara geographic regions. The cities with the highest population density, industrialization and agricultural activity are in the Marmara, Aegean and Mediterranean regions.

The forests composed of Fagus orientalis, Castanea sativa, Abies bornmuelleriana, Abies nordmanniana, Rhododendron ponticum and R. flavum are dominant in the Black

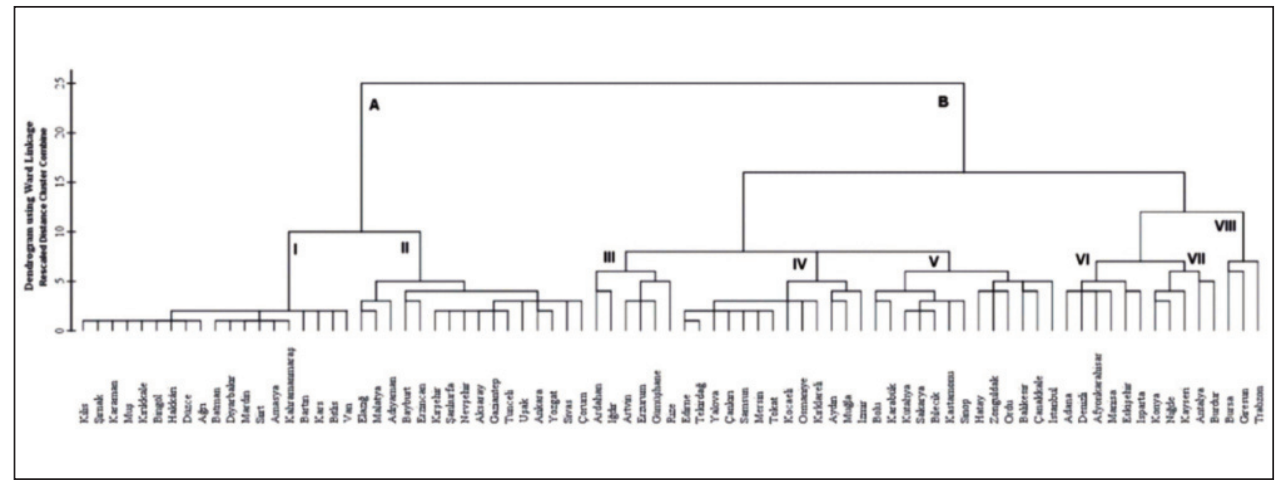

Fig. 3. Dendrogram of similarities of provinces based on lichen diversity. 
Table 4. The most common species in the geographical regions of Turkey.

\begin{tabular}{|c|c|c|c|c|c|c|c|c|}
\hline The geographic regions of Turkey & & 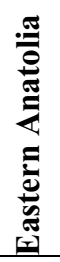 & 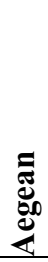 & 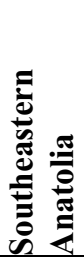 & 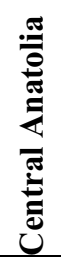 & 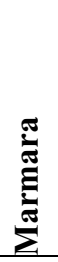 & 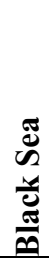 & 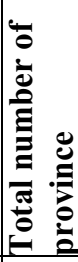 \\
\hline Number of provinces & 8 & 14 & 8 & 9 & 13 & 11 & 18 & 81 \\
\hline Protoparmeliopsis muralis & 7 & 13 & 8 & 8 & 12 & 10 & 16 & 74 \\
\hline Candelariella aurella & 8 & 9 & 8 & 5 & 12 & 10 & 17 & 69 \\
\hline Candelariella vitellina & 6 & 12 & 8 & 6 & 11 & 10 & 16 & 69 \\
\hline Circinaria calcarea & 8 & 11 & 7 & 7 & 10 & 9 & 14 & 66 \\
\hline Rhizocarpon geminatum & 7 & 12 & 8 & 3 & 11 & 11 & 14 & 66 \\
\hline Athallia holocarpa & 8 & 9 & 7 & 4 & 11 & 10 & 17 & 66 \\
\hline Myriolecis crenulata & 8 & 10 & 7 & 6 & 11 & 9 & 14 & 65 \\
\hline Phaeophyscia nigricans & 6 & 9 & 8 & 3 & 10 & 10 & 16 & 62 \\
\hline Phylliscium demangeonii & 7 & 6 & 8 & 2 & 11 & 11 & 16 & 61 \\
\hline Caloplaca cerina & 6 & 9 & 8 & 4 & 9 & 9 & 15 & 60 \\
\hline Circinaria caesiocinerea & 6 & 10 & 7 & 5 & 10 & 8 & 14 & 60 \\
\hline Lobothallia praeradiosa & 6 & 9 & 8 & 6 & 8 & 7 & 15 & 59 \\
\hline Lecidella carpathica & 7 & 6 & 8 & 2 & 8 & 11 & 16 & 58 \\
\hline Circinaria contorta & 7 & 10 & 7 & 4 & 11 & 6 & 13 & 58 \\
\hline Xanthoria parietina & 7 & 6 & 8 & 1 & 10 & 10 & 15 & 57 \\
\hline Xanthoparmelia pulla & 8 & 7 & 8 & 3 & 10 & 7 & 12 & 55 \\
\hline Physcia adscendens & 7 & 7 & 7 & 3 & 9 & 9 & 13 & 55 \\
\hline Verrucaria nigrescens & 6 & 8 & 7 & 6 & 9 & 8 & 10 & 54 \\
\hline Tephromela atra & 6 & 5 & 8 & 2 & 11 & 10 & 12 & 54 \\
\hline Aspicilia cinerea & 7 & 9 & 6 & 3 & 7 & 7 & 15 & 54 \\
\hline Blastenia crenularia & 6 & 7 & 7 & 6 & 8 & 8 & 11 & 53 \\
\hline Acarospora cervina & 7 & 8 & 5 & 6 & 11 & 5 & 11 & 53 \\
\hline Xanthocarpia lactea & 6 & 8 & 5 & 6 & 10 & 7 & 11 & 53 \\
\hline Lecanora chlarotera & 6 & 4 & 8 & 1 & 9 & 11 & 14 & 53 \\
\hline Xanthoria elegans & 6 & 12 & 5 & 2 & 11 & 3 & 14 & 53 \\
\hline Pyrenodesmia erodens & 6 & 8 & 6 & 7 & 9 & 5 & 11 & 52 \\
\hline Lecidella asema & 8 & 8 & 7 & 4 & 10 & 4 & 10 & 51 \\
\hline Diplotomma epipolium & 5 & 8 & 6 & 4 & 10 & 7 & 11 & 51 \\
\hline Squamarina cartilaginea & 7 & 6 & 8 & 4 & 5 & 10 & 10 & 50 \\
\hline
\end{tabular}

Numbers indicated the number of province where the species are found. 
Sea region (Akman 1995). A mainly temperate lichen requiring humid conditions (Nimis 2016) such as Alyxoria varia (Pers.) Ertz \& Tehler, Arthonia radiata (Pers.) Ach., Bryoria capillaris (Ach.) Brodo \& D. Hawksw., Lecanora intumescens (Rebent.) Rabenh., Lepraria elobata Tønsberg and Nephroma laevigatum Ach. have a wide distribution in the Euro-Siberian phytogeographic region. Rinodina septentrionalis Malme which has a subarctic-subalpine to boreal-montane distribution and found on shrubs in open situations, especially common on Rhododendron (Nimis 2016) is a common species in the EuroSiberian phytogeographic region of Turkey (Table 5).

Bagliettoa calciseda (DC.) Gueidan \& Cl.Roux, B. parmigera (J.Steiner) Vězda \& Poelt, Caloplaca haematites (Chaub. ex St.-Amans) Zwackh and Xanthoria calcicola Oxner, mainly Mediterranean to mild-temperate species, have a widely distribution in the Mediterranean phytogeographic region of Turkey.

Aspicilia desertorum (Kremp.) Mereschk., Calogaya biatorina (A.Massal.) Arup, Frödén \& Søchting, C. decipiens (Arnold) Arup, Frödén \& Søchting, C. lobulata (Flörke) Arup, Frödén \& Søchting, Circinaria esculenta (Pall.) Sohrabi, Rhizocarpon viridiatrum (Wulfen) Körb., Rhizoplaca chrysoleuca (Sm.) Zopf and Rinodina beccariana Bagl. are most frequent in areas with a dry - continental and subcontinental climate in the IranoTuranian phytogeographic region of Turkey.

The dendrograms of similarities based on lichen diversity of provinces using Ward's Hierarchical Clustering method with Squared Euclidean Distance were obtained. Here, all of 81 provinces were evaluated. Provinces were divided into two main groups according to the similarity in species diversity (Fig. 3). Generally, group A consists of the provinces in the Irano-Turanian phytogeographical region, while group B includes the provinces in Euro-Siberian and Mediterranean phytogeographical regions. Group A was divided into two subgroups (I - II). Group I (red in Fig. 4) consists of Ağrı, Amasya, Bartın, Batman, Bingöl, Bitlis, Diyarbakır, Düzce, Hakkâri, Kahramanmaraş, Karaman, Kars, Kırıkkale, Kilis, Mardin, Muş, Siirt, Şırnak and Van provinces; mean species diversity value (MSDV) $=3.40 \pm 0.80$. Group II (dark green in Fig. 4) consists of Adiyaman, Aksaray, Ankara, Bayburt, Çorum, Elazı̆̆g, Erzincan, Gaziantep, Kırşehir, Malatya, Nevşehir, Sivas, Şanlıurfa, Tunceli, Uşak and Yozgat provinces; MSDV $=5.06 \pm 0.29$. On the other hand, Group B was divided into six subgroups (III-VIII). Group III (dark blue in Fig. 4) consists of Ardahan, Artvin, Erzurum, Gümüşhane, Iğdır and Rize provinces; MSDV=5.61 \pm 0.21 . Group IV (light blue in Fig. 4) is Aydın, Çankırı, Edirne, İzmir, Kırklareli, Kocaeli, Mersin, Muğla, Osmaniye, Samsun, Tekirdağ, Tokat and Yalova provinces; MSDV = 4.88 \pm 0.41 ; Group V (violet in Fig. 4) is Balıkesir, Bilecik, Bolu, Çanakkale, Hatay, İstanbul, Karabük, Kastamonu, Kütahya, Ordu, Sakarya, Sinop and Zonguldak provinces; MSDV = 5.57 \pm 0.26 ; Group VI (orange in Fig. 4) is Adana, Afyonkarahisar, Denizli, Eskişehir, Isparta and Manisa; MSDV = 5.81 \pm 0.19 ; Group VII (yellow in Fig. 4) is Antalya, Burdur, Kayseri, Konya and Niğde provinces; MSDV = 5.88 \pm 0.20 ; Group VIII (light green in Fig. 4) consists of Bursa, Giresun and Trabzon provinces, MSDV $=6.38 \pm 0.01$ (Fig. 4). Similarities of the provinces based on dendrogram analysis are weakly supporting the grouping in Fig. 2 and not statistically significant.

The PCA results based on lichen diversity of the provinces in the geographical regions of Turkey are shown in Fig. 5; the first two axes represent $23.5 \%$ of the total variance. The first axis is associated with the shannon diversity values in the provinces of Turkey and the 
Table 5. Some common species of the phytogeographical regions of Turkey.

\begin{tabular}{|c|c|c|c|}
\hline The phytogeographic regions & Euro-Siberian & Irano-Turanian & Mediterranean \\
\hline Total number of provinces & 22 & 43 & 16 \\
\hline Acrocordia gemmata & 11 & 1 & 5 \\
\hline Alyxoria varia & 12 & 2 & 5 \\
\hline Arthonia radiata & 15 & 2 & 5 \\
\hline Aspicilia desertorum & 2 & 30 & 7 \\
\hline Bagliettoa calciseda & 7 & 14 & 9 \\
\hline Bagliettoa marmorea & 3 & 9 & 9 \\
\hline Bagliettoa parmigera & 3 & 4 & 10 \\
\hline Bagliettoa parmigerella & 0 & 2 & 7 \\
\hline Bryoria capillaris & 11 & 8 & 5 \\
\hline Buellia griseovirens & 9 & 7 & 11 \\
\hline Calogaya biatorina & 5 & 20 & 6 \\
\hline Calogaya decipiens & 9 & 26 & 7 \\
\hline Calogaya lobulata & 6 & 19 & 3 \\
\hline Calogaya persica & 0 & 13 & 1 \\
\hline Caloplaca haematites & 3 & 7 & 13 \\
\hline Caloplaca stillicidiorum & 3 & 14 & 3 \\
\hline Caloplaca teicholyta & 4 & 15 & 6 \\
\hline Candelariella coralliza & 7 & 18 & 3 \\
\hline Cetraria islandica & 9 & 11 & 2 \\
\hline Circinaria esculenta & 2 & 16 & 1 \\
\hline Circinaria fruticulosa & 0 & 12 & 1 \\
\hline Enchylium polycarpon & 7 & 16 & 8 \\
\hline Enchylium tenax & 9 & 23 & 13 \\
\hline Flavoparmelia caperata & 19 & 10 & 7 \\
\hline Gallowayella fulva & 5 & 19 & 3 \\
\hline Glypholecia scabra & 2 & 13 & 3 \\
\hline Gyalolechia bracteata & 0 & 12 & 3 \\
\hline Gyalolechia desertorum & 0 & 7 & 0 \\
\hline Hafellia disciformis & 12 & 4 & 5 \\
\hline Heteroplacidium compactum & 1 & 12 & 4 \\
\hline Immersaria athroocarpa & 3 & 14 & 6 \\
\hline Lathagrium cristatum & 11 & 24 & 14 \\
\hline Lecanora argopholis & 2 & 11 & 1 \\
\hline Lecanora bicincta & 1 & 9 & 2 \\
\hline Lecanora intumescens & 13 & 4 & 6 \\
\hline
\end{tabular}


Table 5. continued.

\begin{tabular}{|l|c|c|c|}
\hline Lecanora poliophaea & 9 & 20 & 4 \\
\hline Lecanora sulphurea & 1 & 11 & 3 \\
\hline Lecidea albofuscescens & 5 & 22 & 5 \\
\hline Lecidea fuliginosa & 9 & 24 & 12 \\
\hline Lecidella asema & 10 & 26 & 15 \\
\hline Lobarina scrobiculata & 4 & 17 & 3 \\
\hline Lobothallia farinosa & 1 & 15 & 5 \\
\hline Polyblastia dermatodes & 6 & 21 & 4 \\
\hline Polycauliona candelaria & 9 & 15 & 5 \\
\hline Polysporina pusilla & 2 & 10 & 4 \\
\hline Protoparmeliopsis achariana & 6 & 25 & 8 \\
\hline Protoparmeliopsis bolcana & 3 & 22 & 6 \\
\hline Psora cerebriformis & 4 & 20 & 11 \\
\hline Rhizocarpon viridiatrum & 6 & 20 & 2 \\
\hline Rhizoplaca chrysoleuca & 7 & 24 & 2 \\
\hline Rinodina beccariana & 5 & 21 & 8 \\
\hline Rinodina bischoffii & 3 & 24 & 7 \\
\hline Tuckermannopsis chlorophylla & 11 & 4 & 8 \\
\hline Umbilicaria cylindrica & 6 & 12 & 0 \\
\hline Umbilicaria decussata & 4 & 11 & \\
\hline Numbers indicated the number of province & 5 & 2 \\
\hline
\end{tabular}

Numbers indicated the number of province where the species are found.

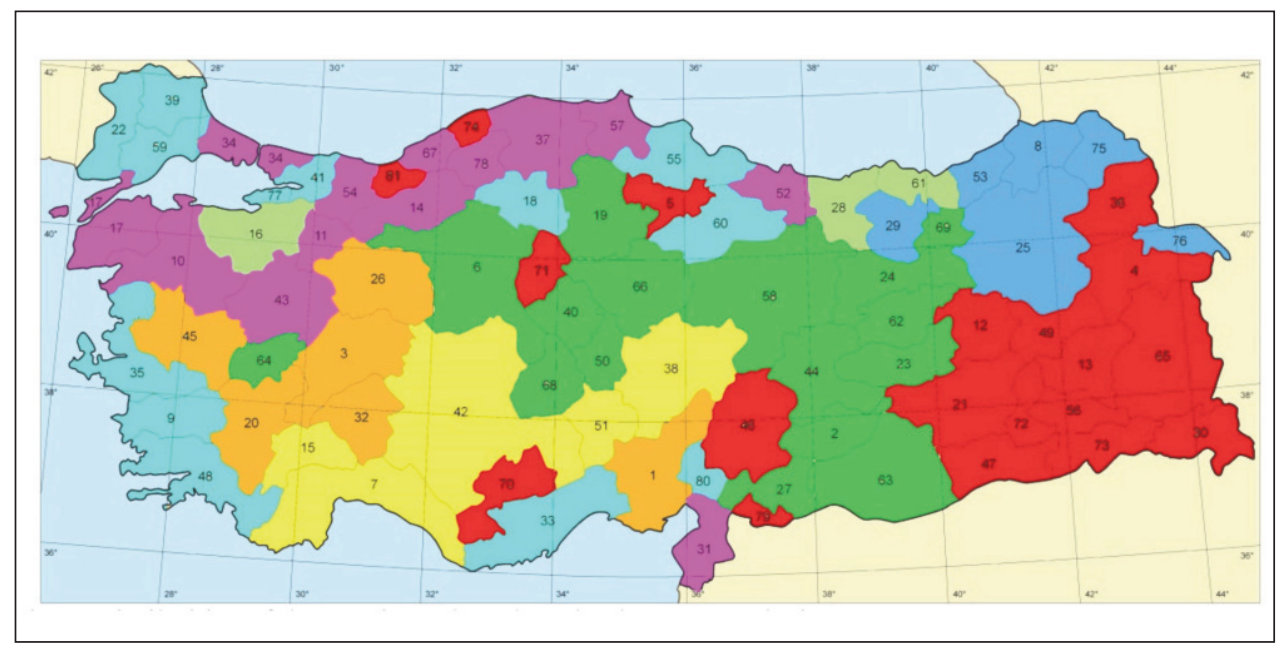

Fig. 4. Similarities of the provinces based on dendrogram analysis. 


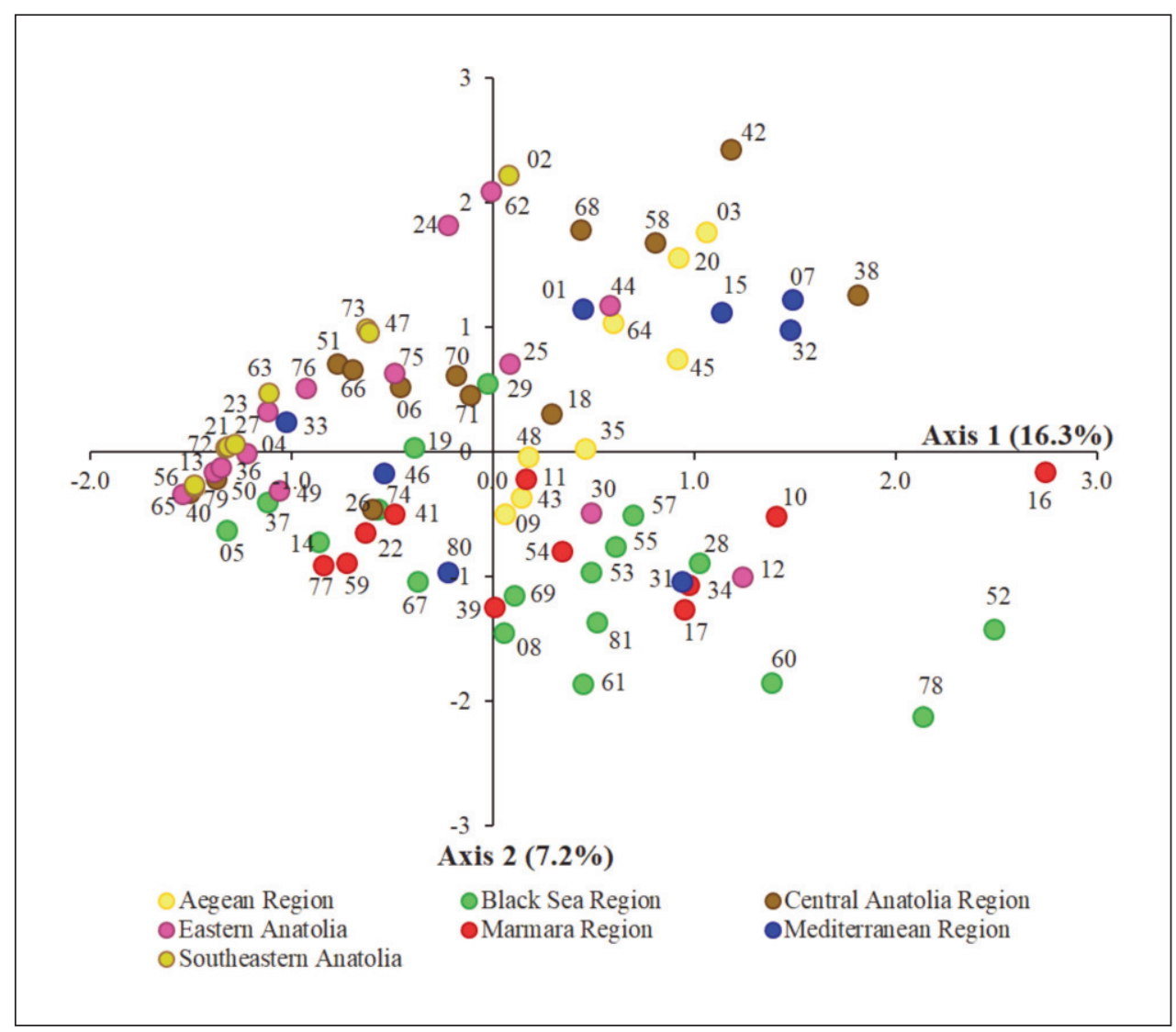

Fig. 5. PCA ordination diagram of geographical regions based on lichenized fungi in 81 provinces. The numbers indicate the codes of the provinces given in Table 3 .

second axis is associated with both geographical and phytogeographical regions of Turkey (Table 6). The provinces with small lichen diversity value are the left of axis 1 and those with the largest diversities are to the right. Generally, Eastern, Southeastern Anatolia and Central Anatolia regions are to be found on the upper left side of axis 2 and the Aegean and Mediterranean regions were on the upper right side of axis 2; on the other hand, the Black Sea and Marmara regions of Turkey are located on the lower side of axis 2 . The most different geographical region in terms of lichen diversity was southeast Anatolia; this region was similar to the eastern and central Anatolian (Table 7).

The PCA results based on lichen diversity of the provinces in the phytogeographical regions of Turkey are shown in Fig. 6. Irano-Turanian phytogeographical region is located on the upper side of axis 1 and the Euro-Siberian and Mediterranean are on the lower side of axis 1 . The Irano-Turanian phytogeographical region was significantly different from the colchic sector of the Euro-Siberian and Mediterranean (Table 8). 
Table 6. Correlations between mean species diversity value of the geographic and phytogeographic regions, and axes.

\begin{tabular}{|l|c|c|c|c|}
\hline \multicolumn{5}{|c|}{ Pearson Correlation Sig. (2-tailed) N=81 } \\
\hline & Axis1 & Axis2 & $\begin{array}{c}\text { Geographical } \\
\text { regions }\end{array}$ & $\begin{array}{c}\text { Phytogeograpical } \\
\text { regions }\end{array}$ \\
\hline Geographical regions & 0.125 & $\mathbf{- 0 . 4 7 6}^{* *}$ & & \\
\hline Phytogeograpical regions & -0.018 & $\mathbf{0 . 4 7 9}^{* *}$ & $\mathbf{- 0 . 6 9 7}^{* *}$ & \\
\hline Shannon Diversity & $\mathbf{0 . 8 9 4}^{* * *}$ & 0.096 & 0.094 & 0.012 \\
\hline
\end{tabular}

**. Correlation with significance at the 0.01 level (2-tailed).

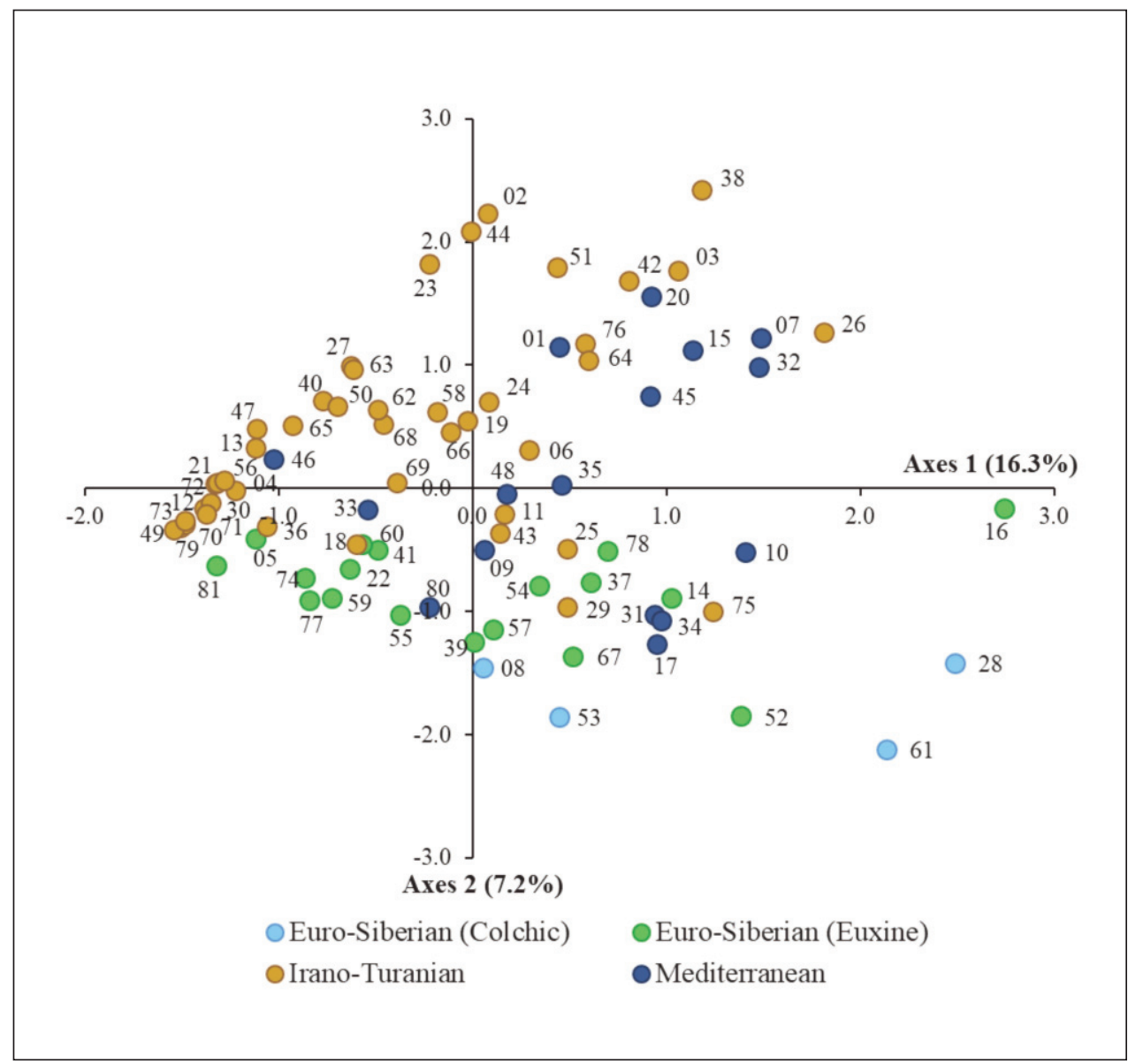

Fig. 6. PCA ordination diagram of phytogeographical regions based on lichenized fungi in 81 provinces. The numbers indicate the traffic codes of the provinces and are given in Table 3. 
Table 7. Differences in mean species diversity value of geographical regions of Turkey determined with Tukey's HSD test.

\begin{tabular}{|c|c|c|c|c|c|c|c|c|}
\hline $\begin{array}{l}\text { Geographical } \\
\text { regions }\end{array}$ & $\mathbf{N}$ & Mean \pm SD & 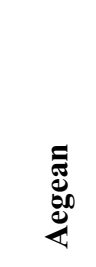 & 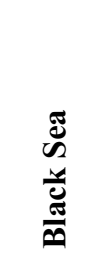 & 吾 & 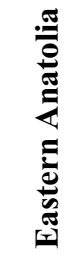 & & 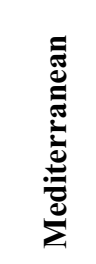 \\
\hline Aegean & 8 & $5.55 \pm 0.23$ & - & 0.33 & 0.71 & 0,99 & 0.31 & 0.16 \\
\hline Black Sea & 18 & $5.23 \pm 0.80$ & -0.33 & - & 0.38 & 0.67 & -0.01 & -0.16 \\
\hline Central Anatolia & 13 & $4.84 \pm 1.15$ & -0.71 & -0.38 & - & 0.28 & -0.40 & -0.55 \\
\hline Eastern & 14 & $4.56 \pm 1.11$ & $-0,99$ & -0.67 & -0.28 & - & -0.68 & -0.83 \\
\hline Marmara & 11 & $5.24 \pm 0.68$ & -0.31 & 0.01 & 0.40 & 0.68 & - & -0.15 \\
\hline Mediterranean & 8 & $5.39 \pm 0.69$ & -0.16 & 0.16 & 0.55 & 0.83 & 0.15 & - \\
\hline Southeastern & 9 & $3.81 \pm 1.13$ & $-1.74^{*}$ & $-1.42^{*}$ & -1.03 & -0.75 & $-1.43^{*}$ & $-1.58 *$ \\
\hline
\end{tabular}

*. The mean difference is significant at the 0.05 level.

$\mathrm{N}$ : Number of provinces in the geographical region

Table 8. Differences in mean species diversity value of phytogeographical regions of Turkey determined with Tukey's HSD test.

\begin{tabular}{|l|c|c|c|c|c|}
\hline $\begin{array}{c}\text { Phytogeographical } \\
\text { regions }\end{array}$ & $\mathbf{N}$ & Mean \pm SD & Colchic & Euxine & $\begin{array}{c}\text { Irano - } \\
\text { Turanian }\end{array}$ \\
\hline Euro-Siberian (Colchic) & 4 & $5.94 \pm 0.53$ & & & \\
\hline Euro-Siberian (Euxine) & 18 & $4.97 \pm 0.77$ & -0.97 & & \\
\hline Irano-Turanian & 43 & $4.62 \pm 1.12$ & $-\mathbf{1 . 3 2} *$ & -0.35 & \\
\hline Mediterranean & 16 & $5.52 \pm 0.51$ & -0.42 & 0.55 & $\mathbf{0 . 9 0}^{*}$ \\
\hline
\end{tabular}

$*$. The mean difference is significant at the 0.05 level.

$\mathrm{N}$ : Number of provinces in the phytogeographical region

The geographical regions of Turkey were also divided into three main groups according to similarities in species diversity (Fig. 7): (1) Aegean, Mediterranean and Marmara, (2) Central, Eastern, and Southeastern Anatolia geographical regions and (3) the Black sea region.

The geographical regions of Turkey were divided into two groups at the first level. Peltigera neopolydactyla (Gyeln.) Gyeln. and Phaeophyscia rubropulchra (Degel.) Moberg were the indicator species of the Black sea region, and for the other geographical regions Diplotomma epipolium (Ach.) Arnold, Phylliscum demangeonii (Moug. \& Mont.) Nyl., Psora decipiens (Hedw.) Hoffm. and Sarcogyne regularis Körb. At the second level, Aegean, Mediterranean and Marmara geographic regions were separated from the Central, Eastern, and Southeastern Anatolia geographical regions. Indicator species for the first 


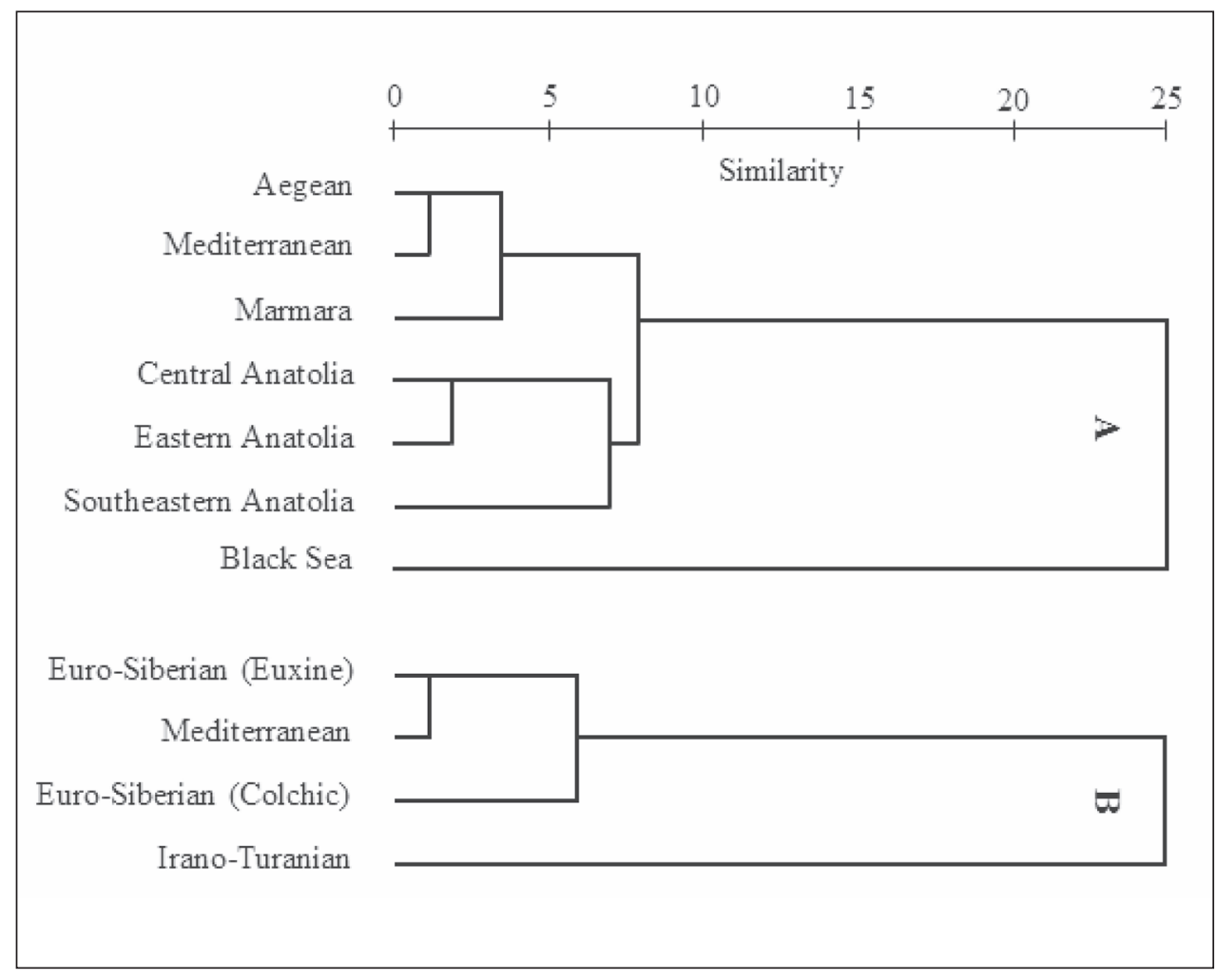

Fig. 7. Dendrogram of the geographical (A) and phytogeographical (B) regions of Turkey based on lichenized fungi.

group are Cladonia coniocraea (Flörke) Spreng, Cl. convoluta (Lam. ) Anders, Evernia prunastri (L.) Ach., Flavoparmelia caperata (L.) Hale, Lobaria linita (Ach.) Rabenh., Lepra albescens (Huds.) Hafellner, Pertusaria paramerae A. Crespo \& Vezda, Placynthium nigrum (Huds.) Gray and Ramalina carpatica Körb. Indicator species for Central, Eastern, and Southeastern Anatolia geographical regions are Aspicilia desertorum (Kremp.) Mereschk., A. intermutans (Nyl.) Arnold, Lecanora poliophaea (Eahlenb.) Ach., Lecidea albofuscescens Nyl., Lobarina scrobiculata (Scop.) Nyl. ex Cromb., Rhizocarpon viridiatrum (Wulfen) Körb., Rhizoplaca chrysoleuca (Sm.) Zopf and Rinodina beccariana Bagl.

The phytogeographical regions of Turkey were divided into two main groups (1) EuroSiberian and Mediterranean phytogeographical regions and (2) Irano-Turanian. Cladonia coniocraea (Flörke) Spreng., Cl. convoluta (Lam.) Anders., Cl. fimbriata (L.) Fr., Cl. foliacea (Huds.) Willd., Evernia prunastri (L.) Ach., Flavoparmelia caperata (L.) Hale, Lobaria linita (Ach.) Rabenh., Lepra albescens (Huds.) Hafellner, Placynthium nigrum (Huds.) Gray and Ramalina carpatica Körb. are indicator species of the Euro-Siberian and Mediterranean phytogeographical regions. Differentiating species for Irano-Turanian are 
Aspicilia desertorum (Kremp.) Flagey, Aspicilia intermutans (Nyl.) Arnold, Lecanora poliophaea (Wahlenb.) Ach., Lecidea albofuscescens Nyl. and Lobarina scrobiculata (Scop.) Nyl. ex Cromb.

Of 16,173 items of data analysed, $26.7 \%$ were recorded from the Black Sea region and $15.8 \%$ from the Marmara region. The least records were from the southeast Anatolia region with $3.9 \%$ (Fig. 8). On the other hand, the largest number of lichens occurred in the phytogeographic regions of Irano-Turanian (41.5\%); this was followed by Euro-Siberian (31.4\%) and Mediterranean regions (27.1\%) (Fig. 9). 141 taxa were found only in the colchic part of the Euro-Siberian phytogeographic region, while 100 taxa were found in the Euxine part. The number of taxa which only occurred in the Irano Turanian phytogeographic region was 197, and 173 in the Mediterranean. 483 taxa were recorded in all phytogeographic regions of Turkey.

\section{Discussion}

The number of species known from Turkey in 1995 was about 800, and this number was estimated to be c. 3000 (John \& Nimis 1998). Recently, a total of 1887 taxa consisting of 208 lichenicolous and 1679 lichenized fungi has been listed by John \& Türk (2017) and an additional 92 taxa by John \& al. (2020). We consider it realistic that with the c. 2000 species currently known, only about $2 / 3$ of the species occurring in Turkey have been recorded. Many regions are still unexplored, e. g. the provinces of Karaman (11 species), Kilis (8), Muş (10) and Şırnak (11). They urgently are in need of intensive field work.

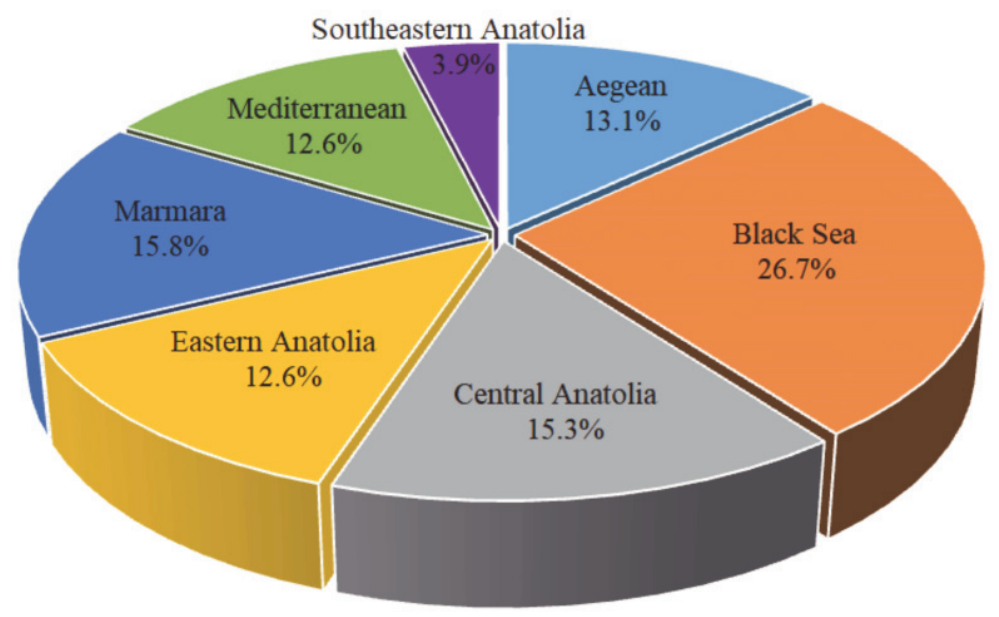

Fig. 8. Percentages of taxa in geographical regions of Turkey. 


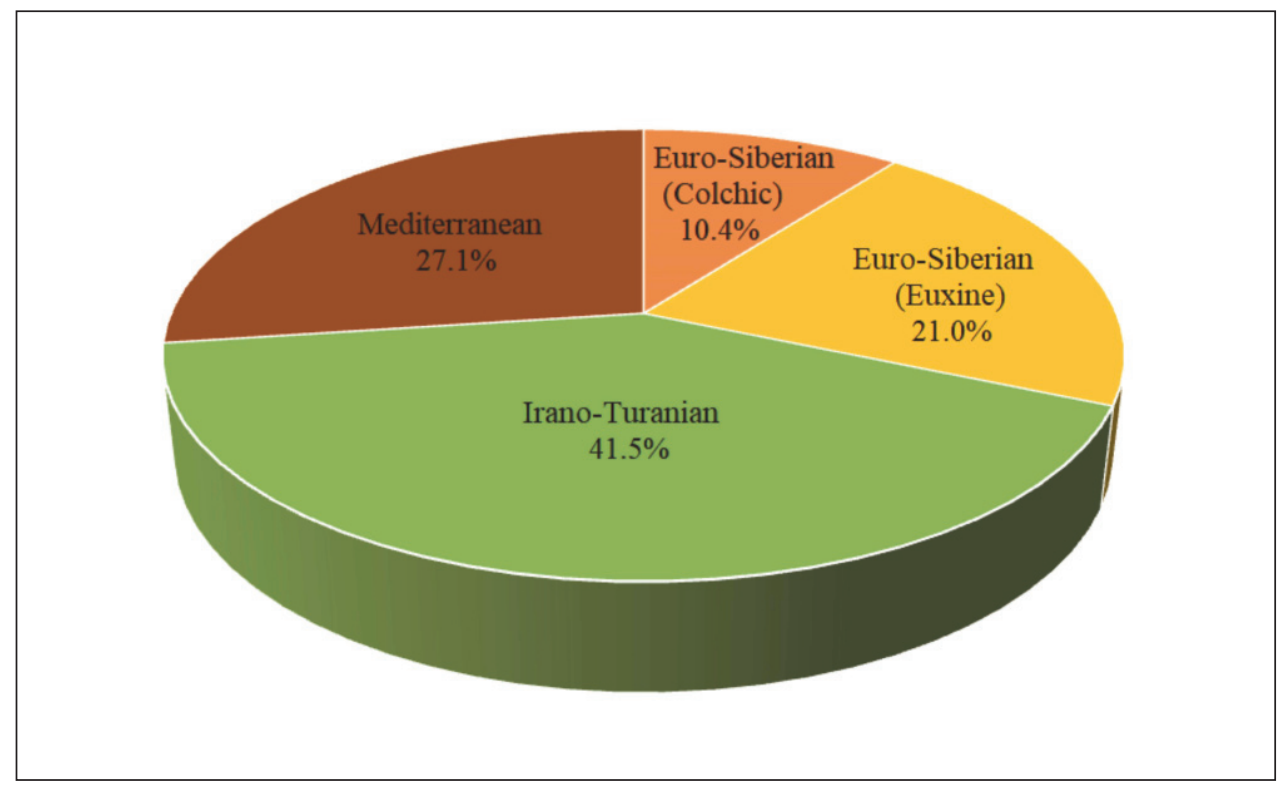

Fig. 9. Percentages of taxa in the phytogeographical regions of Turkey.

Many "Mediterranean" lichens are distributed far beyond the Mediterranean region of Turkey, some of them extending throughout the Mediterranean, Irano-Turanian and EuroSiberian phytogeographic regions. Pseudevernia furfuracea (L.) Zopf and Tuckermannopsis chlorophylla (Willd.) Hale as acidophytic lichens (Wolseley \& al. 2006) are common species in black pine forests in Aegean and Mediterranean regions of Turkey (Sevgi \& al. 2019). Hypocenomyce scalaris (Ach.) M. Choisy which is a species living on acidic tree bark was found in the oldest cedar trees in Mediterranean forests (Sevgi \& al. 2019). This species is especially common in Mediterranean and Aegean regions under the influence of Mediterranean climate of Turkey. Calicioid lichens are indicator species of the age classes of trees. They are more common on old trees than on young trees (Sevgi \& al. 2019). Calicium spp., especially Calicium glaucellum Ach., is common in the Aegean region while Chaenotheca spp. are more frequent in the Black Sea region. Alectoria sarmentosa, Bryoria fuscescens, Calicium salicinum, Chaenotheca chrysocephala, Chrysothrix candelaris, Cyphelium inquinans, Evernia prunastri, Graphina ruiziana, Lecanora chlarotera, L. pallida, Lobaria pulmonaria, Ochrolechia parella, Opegrapha atra, Parmelia saxatilis, P. submontana, P. sulcata, Pertusaria hemisphaerica, Pseudevernia furfuracea, Ramalina farinacea, $R$. thrausta, Schismatomma graphidioides, Usnea florida, U. fulvoreagens and U. subfloridana were found on fir and pine trees in the mixed forest at the vicinity of Bolu province in the Black Sea region (Sevgi \& al. 2016). Similarly, some of these species were found widely in Uludağ fir trees (Öztürk \& Güvenç 2010). Recently, variations of the epiphytic and non-epiphytic lichen diversity in Mediterranean maquis and arborescent matorral habitats have been studied. Species richness and frequency of northern localities of Mediterranean maquis and arborescent matorral habitats were found to be significantly high- 
er and community composition of northern localities was found to be much different than other localities (Tufan Çetin 2019). Of countries neighbouring Turkey, the lichen diversity of Greece is the best known, the checklist of lichenicolous and lichenized fungi containing 1296 species (Abbott 2009), 993 of which are also present in Turkey. Amadiya and Rowanduz districts of Iraq which are bordered to the north by Hakkâri and Şırnak provinces of Turkey are poorly investigated with only 47 species (Almola \& al. 2017), 41 of which are recorded also from Turkey. The lichen biota of Turkey cover a large percentage of the lichen biota of Armenia (59.6\%), Bulgaria (75.2\%), Iran (74.9\%) and Syria (75.9\%) (Table 9). Such correspondences are a consequence of the more extensive lists of the better studied provinces. The difference in the number of shared species with countries in the east of Turkey (Armenia, Georgia) might be caused by the poor exploration of the eastern Turkish provinces.

When we compare the species number of lichens in mapping units of similar size in Turkey and abroad, we can find obvious differences. Here we focus on a few examples from France, Germany and Italy, countries relatively well studied for their lichen inventory.

One of the smallest Turkish provinces, Düzce $\left(2,492 \mathrm{~km}^{2}\right)$ is comparable with the tiny German Federal state of the Saarland $\left(2,571 \mathrm{~km}^{2}\right)$ resulting in 29 versus 501 taxa (John 2020a); and the small province of Aydin $\left(8,116 \mathrm{~km}^{2}\right)$ with 206 species is comparable with Umbria, Italy $\left(8,456 \mathrm{~km}^{2}\right)$ with 556 species (Nimis 2016) or Aveyron, France $\left(8,735 \mathrm{~km}^{2}\right)$ 922 species (Roux \& et coll. 2020).

Medium sized provinces like Mersin $\left(16,010 \mathrm{~km}^{2}\right) 116$ species correspond to Thüringen, Germany (16,202 km²) 1,440 species (Meinunger 2019) and Antalya (20,177 $\left.\mathrm{km}^{2}\right) 432$ species as Van $\left(20,921 \mathrm{~km}^{2}\right) 111$ species correspond to Rheinland-Pfalz, Germany (19,858 km²) 1,014 species (John 2020b).

Ankara $\left(25,632 \mathrm{~km}^{2}\right) 216$ species versus Piemonte, Italy $\left(25,399 \mathrm{~km}^{2}\right) 1,296$ species (Nimis 2016) and Mecklenburg-Vorpommern, Germany $\left(23,295 \mathrm{~km}^{2}\right) 650$ species (Litterski \& Schiefelbein 2017) documents that even outside Turkey the species density is

Table 9. The number of lichen taxa of countries neighbouring Turkey compared with those taxa also found in Turkey.

\begin{tabular}{|l|c|c|}
\hline \multirow{2}{*}{ Neighbouring countries of Turkey } & \multicolumn{2}{|c|}{$\begin{array}{c}\text { The number of lichenicolous and } \\
\text { lichenized fungi }\end{array}$} \\
\cline { 2 - 3 } & Total & Of these also in Turkey \\
\hline Iran (Seaward \& al. 2008) & 645 & 483 \\
\hline Iraq (Almola \& al. 2017) & 47 & 41 \\
\hline Greece (Abbott 2009) & 1296 & 993 \\
\hline Syria (John \& al. 2004) & 399 & 303 \\
\hline $\begin{array}{l}\text { Armenia (Harutyunyan \& al. 2011; Gasparyan } \\
\text { \& al. 2016) }\end{array}$ & 604 & 360 \\
\hline $\begin{array}{l}\text { Georgia (Beeching \& Hodges 2008; Inashvili } \\
\text { \& Batsatsashvili 2010) }\end{array}$ & 700 & 196 \\
\hline $\begin{array}{l}\text { Bulgaria (Mayrhofer \& al. 2005; Shivarov \& } \\
\text { Lökös 2015) }\end{array}$ & 915 & 688 \\
\hline
\end{tabular}


variable in ecologicaly different areas as shown here with the mountain area of Piemonte and the planar country of Mecklenburg-Vorpommern.

The difference between the large province of Konya $\left(40,838 \mathrm{~km}^{2}\right) 360$ species versus Baden-Württemberg, Germany (35,748 $\mathrm{km}^{2}$ ) 1,485 species (Wirth 2008) is evident.

In contrast to these examples the number of species in the best explored provinces of Turkey like Trabzon $\left(4,628 \mathrm{~km}^{2}\right) 605$ species versus Molise, Italy $\left(4,437 \mathrm{~km}^{2}\right) 490$ species (Nimis 2016) or Loire, France $\left(4,437 \mathrm{~km}^{2}\right) 406$ species (Roux \& et coll. 2020) and Bursa $\left(10,813 \mathrm{~km}^{2}\right) 607$ species versus Marche, Italy $\left(9,694 \mathrm{~km}^{2}\right) 542$ species (Nimis 2016) or Gironde, France $\left(9,975 \mathrm{~km}^{2}\right) 453$ species (Roux et coll. 2020) show higher numbers in Turkey.

\section{Conclusions}

The provinces with the highest number of lichen taxa (Bursa, Trabzon, Giresun, Kayseri, Eskişehir- and Antalya) are characterised by a high diversity in geography, geology and climate, connected with research hub. In order to achieve a more realistic assessment of the linkage of lichen occurrence with specific provinces and their habitats, a more uniform survey of the entire territory of Turkey must be reached. For this purpose, a medium intensity of the processing status is sufficient (Sauer 1974).

While the current data set allows for an evaluation of the species range of each province, it only partially reflects the geographic and phytogeographic regions used as a basis. For some regions, the results fit quite well into the postulated distribution, while others look like they are scattered or disjunct. As provinces, the areas studied vary considerably in size and intensity of research, and some are ecologically rather heterogeneous, a uniform grid system might be tested (John 1996b).

Some indicator species are known as widespread and common. As they are rarely recorded in Turkey they here figure as differntiating taxa, like Aspicilia intermutans, Cladonia coniocraea, Diplotomma epipolium, Evernia prunastri, Flavoparmelia caperata, Lepra albescens, Placynthium nigrum, Psora decipiens and Sarcogyne regularis, whereas other species are extremely rare, so Pertusaria paramerae, Lecanora poliophaea, Lecidea albofuscescens and Rinodina beccariana. A more consistent and comprehensive data set will certainly cause some changes.

\section{Acknowledgments}

We are grateful to Prof. Mark Seaward, Leeds, for improving the English and Dr. Michael Lakatos, Kaiserslautern, and two anonymous reviewers for valuable comments on the manuscript.

\section{References}

Abbott, B. F. M. 2009: Checklist of the lichen and lichenicolous fungi of Greece. - Biblioth. Lichenol. 103: 1-368.

Akman, Y. 1995: Türkiye orman vejetasyonu. - Ankara Üniversitesi Fen Fakültesi, Botanik Anabilim Dalı, Ankara: 450 p. 
Almola, Z. S., Al-Nima, B. A. \& Ramadan, N. A. 2017: Lichen diversity in Amadiya and Rowanduz districts in Iraq. - Bangladesh J. Pl. Taxon. 24(1): 23-32. https://doi.org/ 10.3329/bjpt.v24i1.33002

Atalay, İ., Efe, R. \& Öztürk, M. 2014: Ecology and classification of forests in Turkey. - Proc. Social Behav. Sci. 120: 788-805. https://doi.org/10.1016/j.sbspro.2014.02.163.

Beeching, S. \& Hodges, M. 2008: Checklist of Georgia Lichens. - Tbilisi.

Dönmez, A. A. \& Yerli, S. V. 2019: Biodiversity in Turkey. - Global Biodiv 2: 397-442.

Eken, G., Bozdoğan, M., Isfendiyaroğlu, S., Kılıç, D. T. \& Lise, Y. (eds) 2006: Türkiye'nin önemli doğan alanları. - Ankara.

FAO. 2018: Biodiversity of Turkey. Contribution of Genetic Resources to Sustainable Agriculture and Food Systems. - Ankara.

Gasparyan, A., Aptroot, A., Burgaz, A. R., Otte, V., Zakeri, Z., Rico, V. J., Araujo, E., Crespo, A., Divakar, P. K. \& Lumbsch, H. T. 2016: Additions to the lichenized and lichenicolous mycobiota of Armenia. - Herzogia 29(2): 692-705. https://doi.org/10.13158/heia.29.2.2016.529

Güner, A. \& Ekim, T. (eds) 2014: Resimli Türkiye florası, 1. - Istanbul.

Güner, A., Aslan, S., Ekim, T., Vural, M. \& Babaç, M. T. 2016: Türkiye bitkileri listesi (Damarlı bitkiler). - Nezahat Gökyiğit Botanik Bahçesi, Istanbul.

Halıc1, M. G., Candan, M. \& Türk, A. 2012: A key to the peltigericolous fungi in Turkey. Mycotaxon 119: 277-289. https://doi.org/10.5248/119.277

Harutyunyan, S., Wiesmair, B. \& Mayrhofer, H. 2011: Catalogue of the lichenized fungi in Armenia. - Herzogia 24(2): 265-296. https://doi.org/10.13158/heia.24.2.2011.265

Hauck, M. 2011: Site factors controlling epiphytic lichen abundance in northern coniferous forests. - Flora 206: 81-90. https//doi.org/10.1016/j.flora.2010.02.001

Hesselbarth, G., Van Oorscot, H. \& Wagener, S. 1995: Die Tagfalter der Tpürkei, 1. - Bocholt.

Hill, M. O. \& Smilauer, P. 2005: TWINSPAN for Windows version 2.3. - Centre for Ecology and Hydrology, University of South Bohemia, Huntingdon \& Ceske Budejovice, Czech Republic.

Inashvili, T. \& Batsatsashvili, K. 2010: New lichen records from Georgia. - Turkish J. Bot. 34(6): 549-553. https://doi.org/10.3906/bot-0911-247

John, V. 1996a: Preliminary catalogue of lichenized and lichenicolous fungi of Mediterranean Turkey. - Bocconea 6: 173-216.

John, V. 1996b: UTM-grid-mapping and distribution patterns of lichens in Turkey. - Pp. 440-453 in: Öztürk, M. A., Seçmen, Ö. \& Görk, G. (eds) Plant life in southwest and central Asia. Proceedings of the 4th Plant life in Southwest Asia symposium held in Izmir 21-28 may 1995. - Bornova-Izmir.

John, V. 2007: Lichenological studies in Turkey and their relevance to environmental interpretation. - Bocconea 21: 85-93.

John, V. 2020a: Rote Liste und Gesamtartenliste der Flechten (Lichenisierte Pilze) des Saarlandes. 2. Fassung. - PDF-Ausgabe 2020, Saarbrücken und Landsweiler-Reden.

John, V.2020b: Bibliographie der Flechten von Rheinland-Pfalz. - Perspektiven Pfalzmuseum 9: 1-108.

John, V. \& Nimis, P. L. 1998: Lichen flora of Amanos Mountain and the Province of Hatay. - Turkish J. Botany 22: 257-267.

John, V. \& Türk, A. 2017: Türkiye Likenleri Listesi [Checklist of the Lichens of Turkey]. - İstanbul.

John, V., Güvenç, Ş. \& Türk, A. 2020: Additions to the checklist and bibliography of the lichens and lichenicolous fungi of Turkey. - Arch. Lichenol. 19: 1-32.

John, V., Seaward, M.R.D., Sipman, H.J.M. \& Zedda, L. 2004: Lichens and lichenicolous fungi from Syria, including a first checklist. - Herzogia 17: 157-177.

Litterski, B. \& Schiefelbein, U. 2017: Rote Liste der gefährdeten Flechten MecklenburgVorpommerns. 2. Fassung. -Vorpommern. 
Mayrhofer, H., Denchev, C. M., Stoykov, D. Y. \& Nikolova, S. O. 2005: Catalogue of the lichenized and lichenicolous fungi in Bulgaria. - Mycol. Balcan. 2: 3-61.

Nimis, P. L. 2016: The lichens of Italy A second annotated catalogue. - Trieste.

Meinunger, L. 2019. Florenatlas der Flechten des Thüringer Waldes, der Rhön und angrenzender Gebiete. - Haussknechtia Beiheft 20: 1-1404.

Öztürk, Ş. \& Güvenç, Ş. 2010: The distribution of epiphytic lichens on Uludag fir (Abies nordmanniana (Steven) Spach subsp. bornmuelleriana (Mattf.) Coode \& Cullen) forests along an altitudinal gradient (Mt. Uludag, Bursa, Turkey). - Ekoloji 74: 131-138.

Roux, C., Monnat, J.-Y., Gonnet D. \& al. 2020: Catalogue des lichens et champignons lichénicoles de France métropolitaine. $3^{\mathrm{e}}$ éd. - Fontainebleau.

Sauer, E. 1974: Probleme und Möglichkeiten großmaßstäblicher Kartierungen. - Göttinger Flor. Rundbriefe 1: 6-24.

Seaward, M. R. D., Sipman, H. J. M. \& Sohrabi, M. 2008: A revised checklist of lichenized, lichenicolous and allied fungi for Iran. - Sauteria 15: 459-520.

Şekercioğlu, Ç. H., Anderson, S., Akçay, E., Bilgin, R., Can, Ö.E., Semiz, G., Tavşanoğlu, Ç., Yokeş, M. B., Soyumert, A., İpekdal, K., Sağlam, İ. K., Yücel, M. \& Dalfes, H. N. 2011: Turkey’s globally important biodiversity in crisis. - Biol. Conserv. 144: 2752-2769.

Sevgi, E., Yılmaz, O. Y., Çobanoğlu Özyiğitoğlu, G., Tecimen, H. B. \& Sevgi, O. 2019: Factors Influencing Epiphytic Lichen Species Distribution in a Managed Mediterranean Pinus nigra Arnold Forest. - Diversity 11: 59. http://dx.doi.org/10.3390/d11040059.

Sevgi, O., Çobanoğlu, G. \& Sevgi, E. 2016: Effect of forest habitat on the distribution of lichen species in Şerif Yüksel research forest (Bolu, Turkey). - Pak. J. Bot. 48(2): 581-588, 2016.

Shivarov, V.V. \& Lökös, L. 2015: New records and rare species of pyrenocarpous lichen-forming fungi from Bulgaria. - Studia Bot. Hung. 46(2): 111-118.

Ter Braak, C.J.F. \& Smilauer, P. 2002: CANOCO Reference Manual and Cano Draw for Windows User's Guide: Software for Canonical Community Ordination (Version 4.5). - Ithaca, New York.

Tufan Çetin, Ö. 2019: Determination of lichen diversity variations in habitat type of Mediterranean maquis and arborescent matorral. - Appl. Ecol. Environ. Res. 17(4): 10173-10193. http://dx.doi.org/10.15666/aeer/1704_1017310193

Wirth, V. 2008: Rote Liste und Artenverzeichnis der Flechten Baden-Württembergs. - BadenWürttemberg.

Wolseley, P. A., James, P. W., Theobald, M. R. \& Sutton, M. A. 2006: Detecting changes in epiphytic lichen communities at sites affected by atmospheric ammonia from agricultural sources. Lichenologist 38(2): 161-176. http://dx.doi.org/10.1017/S0024282905005487

Şaban Güvenç, Volker John \& Ayşen Türk

Address of authors:

Şaban Güvenç ${ }^{1 *}$, Volker John² \& Ayşen Türk ${ }^{3}$,

${ }^{1}$ Bursa Uludağ University, Faculty of Arts and Sciences, Department of Biology, 16059 Görükle, Bursa, Turkey. E-mail: saban@uludag.edu.tr

${ }^{2}$ Bietschieder Institut für Natur und Kultur, Kaiserslauterer Strasse 86, 67098 Bad Dürkheim, Deutschland. E-mail: volkerjohn@t-online.de

${ }^{3}$ Eskişehir Technical University, Faculty of Science, Department of Biology, 26555 Tepebaşı, Eskişehir, Turkey. E-mail: aturk@eskisehir.edu.tr

*Corresponding author 